\author{
Hendriko Hendriko \\ Mechanical Department, Politeknik \\ Caltex Riau,Rumbai, Pekanbaru, \\ Indonesia
}

\section{A hybrid Analytical and Discrete Based Methodology to Calculate Path Scallop of Helical Toroidal Cutter in Five-Axis Milling}

This paper presents a new method to calculate path scallop height of toroidal cutter during free-form surface machining in five-axis milling. The scallop height was defined as the distance between the tool intersection point and the normal point on the part surface. The tool intersection point was determined analytically by implementing the grazing method to define the swept curve of toroidal cutter. Meanwhile the normal surface on the part surface was determined using a hybrid analytical and discrete based methodology. The part surface was discretized by a number of normal vectors, then, they were used for defining the part surface mathematically. In this study, the effect of helical angle of cutting edge was taken into consideration in the model development. The proposed model was successfully used to generate the path scallop data for two model parts with free-form surface profiles. The effect of helical angle to the scallop height was also tested and the results showed that the helical angle tends to decrease the scallop height. The verification test to check the accuracy of the proposed method was performed and the results proved that the method was accurate.

Keywords:five-axis milling, scallop height, toroidal cutter, helical angle

\section{INTRODUCTION}

In milling operation, there are three parameters that are commonly used to define the quality of the machined surface: 1) machining tolerance, 2) scallop height, and 3) surface roughness. The desired surface quality should be taken into account in designing the machining process [1]. In multi-axis milling, the scallop height gives the most significant effect to the accuracy of machined surface. There are four main factors that influence the scallop height, 1) cutting tool geometry, 2) tool orientation, 3) part surface geometry, and 4) the distance between adjacent tool paths (step over). In order to achieve the expected surface quality, the scallop must be well controlled. However, due to the complexity of the part surface and tool orientation, the scallop height is difficult to calculate and it cannot be represented easily. The method to determine the scallop height during sculptured surface machining in five-axis milling is still a major challenge.

Several studies [2-5] developed models for calculating the scallop height for ball-end mill to achieve an optimal tool path. Most of the proposed method calculated the scallop height using analytical approaches. Analytical approach was used to calculate

Received: June 2017, Accepted: February 2018

Correspondence to: Dr Hendriko

Mechanical Engineering, Politeknik Caltex Riau,

Rumbai, Pekanbaru, Indonesia, 28265

Email: hendriko@pcr.ac.id

doi:10.5937/fmet1804552H

(C) Faculty of Mechanical Engineering, Belgrade. All rights reserved the cut geometry and scallop height in five axis milling because it was much faster and more accurate when compared to the discrete approaches [6-8]. Several researchers [9-13] investigated the effect of both inclination fand tilt angle to the scallop height in fiveaxis milling. The studies showed that, with the same tool inclination angle, a flat-end tool results in the smallest scallop height compared with a toroidal and a ball-end tools. The scallop height does not vary with the inclination angle when cutting is using a ball-end tool, while it is significantly reduced for a toroidal tool at small inclination angles. In more detail, a flat-end tool even gives more scallop height reduction than the toroidal tool with the same inclination angle. The higher the corner radius of a toroidal tool, the higher the scallop height is, and vice versa.Numerous studies have been performed to investigate the effect of tool inclination angle to the scallop height. In contrast to this, the study on the effect of helical angle to the scallop height is still lack.

Many analytical studies [14-22] addressed the issue on toroidal cutter in five-axis milling by simply approximating an inclined cutter geometry by two common primitive geometries, either circle or ellipse. Senatore et al. [16] represent the tool swept envelope by calculating the effective radius of toroidal cutter due to the inclination angle. Then, the scallop height with respect to radius of part surface is calculated and finally the optimal step-over can be determined. Others studies [17-22] defined the inclined flat and ball end mills as an 
ellipse. Mathematically, the shape of swept curves of inclined flat and ball end mill, which are projected into $2 \mathrm{D}$, can be precisely determined by parametric equation of ellipse curve. However, this approach is not applicable to toroidal cutter. Toroidal cutter is decomposed into cylindrical surface and toroidal surface. Consequently, determining the swept curve when the inclination angle exists becomes much more complicated. To overcome such problem, Kiswanto et al. [6] developed an analytical method, which is called grazing method, to define the swept curve of an inclined toroidal cutter. This method was proven effective to calculate cutter workpiece engagement in five-axis milling.

This paper presents a hybrid method to calculate the scallop height produced by a toroidal cutter during a free-form part surface. The proposed method was a combination of analytical method and the discrete vector based methodology, in which discrete normal vectors were used to describe the part surface as proposed by [8]. The present study was addressed to improve the drawback of the existing method in representing the swept curve of inclined toroidal cutter.In this study, the grazing method to define the swept curve of inclined toroidal cutter was used to define the intersection point between toroidal cutter of two successive tool paths. Moreover, the effect of helical angle was taken into consideration in the model development.

\section{SWEPT CURVE CALCULATION}

Geometrically, toroidal-end cutter was decomposed into cylindrical and toroidal surface as depicted in Figure 1a. The representation of toroidal surface with respect to the tool coordinate system (TCS) was described by the following equation,

$$
G_{T}(\varphi ; \lambda)\left[\begin{array}{c}
x \\
y \\
z
\end{array}\right]=\left[\begin{array}{c}
\left(r_{m}+r \sin \lambda\right) \sin \varphi \\
\left(r_{m}+r \sin \lambda\right) \cos \varphi \\
r-r \cos \varphi
\end{array}\right]
$$

where $r$ is minor radius of cutter and $r_{m}$ is the distance between cutter centre point and the minor radius. Meanwhile $\lambda$ and $\varphi$ denote the toroidal angle and engagement angle, respectively.

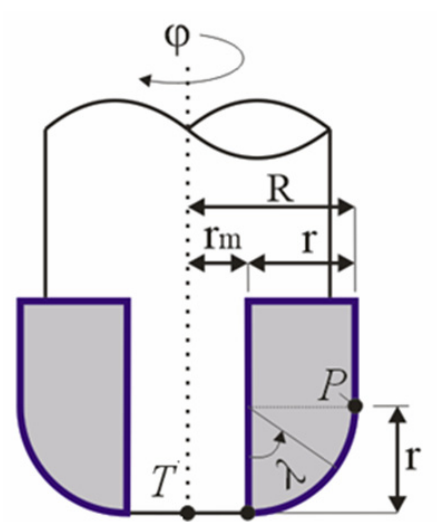

(a)

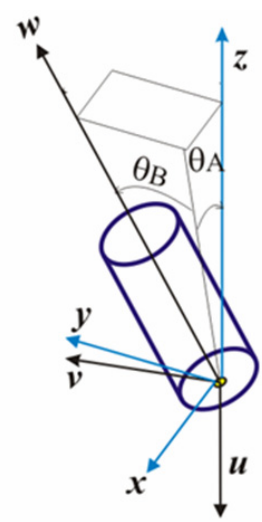

(b)
Figure 1 a) Geometry of cutting tool, b) tool orientation due to inclination angle
In five-axis machining, the tool can be rotated in any direction. Part with sculptured surfaces can be machined efficiently by controlling the tool to move and rotate dynamically with respect to the part surface normal (curvatures). For the purpose of analytical representation of moving surface generation of the cutting tool, appropriate operators of the coordinate system transformations are required. Therefore, two coordinate systems as illustrated in Figure $1 \mathrm{~b}$ were employed to represent the position and orientation of the tool. They are workpiece coordinate system (WCS), which is the reference coordinate frame, and tool coordinate system (TCS). To calculate the coordinate transformation, it should be related to a specific machine kinematics. WCS is a fixed frame which is represented by the basis vector $\mathrm{x}, \mathrm{y}, \mathrm{z}$, while TCS is denoted by $\mathrm{u}, \mathrm{v}, \mathrm{w}$. The operator $[\mathrm{M}]$ to map coordinate system from TCS to WCS involving the tool rotation about $\mathrm{x}$-axis $\left(\theta_{A}\right)$, y-axis $\left(\theta_{B}\right)$ and also translation at $\mathrm{T}$ was expressed as follow,

$[M]=\left[\begin{array}{cccc}\cos \theta_{B} & 0 & \sin \theta_{B} & x_{T} \\ \sin \theta_{A} \sin \theta_{B} & \cos \theta_{A} & -\sin \theta_{A} \cos \theta_{B} & y_{T} \\ \cos \theta_{A} \sin \theta_{B} & \sin \theta_{A} & \cos \theta_{A} \cos \theta_{B} & z_{T} \\ 0 & 0 & 0 & 1\end{array}\right]$ (2)

On the other hand, the local coordinate frame with orthogonal basis vector $u, v, w$, which was located at the cutter contact point (CC-point), was defined as,

$$
\begin{aligned}
& w=\left[\begin{array}{ccc}
\cos \alpha & 0 & \sin \alpha \\
0 & 1 & 0 \\
\sin \alpha & 0 & \cos
\end{array}\right]\left[\begin{array}{lll}
0 & 0 & 1
\end{array}\right]^{T}=\left[\begin{array}{lll}
\sin \alpha & 0 & \cos \alpha
\end{array}\right]^{T} \\
& v=\frac{w \times V_{T}}{\left|w \times V_{T}\right|} ; u=v \times w
\end{aligned}
$$

Despite toroidal cutter was constructed by two surfaces, cylindrical and toroidal surface, the swept curve was only located on the toroidal surface. Swept curve was derived from the method to define grazing point in the swept envelope development. As mentioned by [6], the swept envelope was constructed by three points, forward boundary (egress point), envelope boundary (grazing point) and backward boundary (ingress point). Swept curve was obtained by using the tangency function as follow,

$$
F_{(\vartheta, \varphi, p)}=N_{S_{T}(\vartheta, \varphi, p)} \cdot V_{S_{T}(\vartheta, \varphi, p)}=0
$$

where $N_{S_{T}(\varphi)}$ is the cutter surface normal and $V_{S_{T}}$ is the cutter moving vector. With the same method, the swept curve was constructed by calculating the point coordinate at every engagement angle. The surface normal of an arbitrary point $\boldsymbol{Q}$ on toroidal surface in TCS was described by,

$$
N_{S_{T}}=\frac{\frac{\partial G_{T}}{\partial \lambda}}{\left|\frac{\partial G_{T}}{\partial \lambda}\right|} \times \frac{\frac{\partial G_{T}}{\partial \varphi}}{\left|\frac{\partial G_{T}}{\partial \varphi}\right|}=\left[\begin{array}{c}
\sin \lambda \cdot \sin \varphi \\
\sin \lambda \cdot \cos \varphi \\
-\cos \lambda
\end{array}\right]
$$

When (6) was transformed to the moving frame, it yields to, 


$$
S_{\chi}\left[\begin{array}{l}
x_{S_{\chi}} \\
y_{S_{\chi}} \\
z_{S_{\chi}}
\end{array}\right]=\left[\begin{array}{ccc}
\cos \varphi & -\sin \varphi & 0 \\
\sin \varphi & \cos \varphi & 0 \\
0 & 0 & 1
\end{array}\right] \times\left[\begin{array}{ccc}
\cos \chi & 0 & \sin \chi \\
0 & 1 & 0 \\
\sin \chi & 0 & \cos \chi
\end{array}\right] \times\left[\begin{array}{c}
x_{s} \\
y_{s} \\
z_{s}
\end{array}\right]
$$

The velocity of an arbitrary point $\boldsymbol{Q}$ on the toroidal surface was determined as follow,

$$
V_{G_{T}}=V_{T}+\omega \times \overrightarrow{T Q}
$$

where $\omega$ and $\overrightarrow{T Q}$ denote the angular velocity and the position vector from $T$ to $Q$, respectively. Since the model was developed by assumed that the tool was static, hence there was no angular motion $(\omega=0)$. Therefore, the velocity vector in (8) was equal to $V_{T}$ and the tangential function was determined as follows:

$$
\begin{aligned}
& F_{(\vartheta, \varphi, p)}=\sin \lambda \cdot \sin (\varphi) \cdot\left(V_{T}, u\right)+ \\
& +\sin \lambda \cdot \cos (\varphi) \cdot\left(V_{T}, v\right)-\cos \lambda \cdot\left(V_{T}, w\right)=0
\end{aligned}
$$

Due to $\mathrm{V}_{\mathrm{T}}$ was perpendicular to $\mathrm{v}$, then $\mathrm{V}_{\mathrm{T}} \mathrm{v}=0$. Finally, the toroidal angle of the swept point was calculated as a function of engagement angle as follow:

$$
\lambda_{\varphi)}=\tan ^{-1}\left[\frac{V_{T} \cdot w}{\sin [(\varphi)] \cdot\left(V_{T} \cdot u\right)}\right]
$$

After $\lambda_{(\varphi)}$ was obtained, the coordinate of swept curve point as a function of engagement angle in WCS was calculated as follow,

$$
I_{(\varphi)}\left(x_{1}, y_{1}, z_{1}\right)=[M] G_{T}\left(\varphi_{1} ; \lambda_{(\varphi)}\right)
$$

\section{EFFECT OF HELICAL ANGLE TO THE TOOL ORIENTATION AND SWEPT SURFACE}

The milling cutters with straight teeth have disadvantage in which each edge begins to cut the material on its entire length that creating very strong efforts with discontinuities of the load on the tool. It can be followed by the shock effect that causes vibration that is dangerous to the quality of the machined surface. For this reason, the cutter with helical angle was introduced to eliminate such problem. Helical angle $(\chi)$, which is also called lag angle in solid cutter, makes the cutting tool engages with the workpiece gradually. The existence of helical angle makes the length of cut larger. In this section, the impact of the helical angle to the actual tool orientation and the shape of swept surface will be discussed.

\subsection{Identifying the tool mapping operator and the tool orientation angles during five-axis milling}

When a helical angle is introduced to the cutting tool, it changes the orientation of the cutting edge. The orientation of the cutting edge is not in the same direction to the orientation of the cutting tool. By assuming that the tool moves in the $X$-direction, a helical angle makes the tool rotates about the $Y$-axis as depicted by Figure 2. The actual cutting edge orientation at every engagement angle can be determined by calculating two representative points on the cutting edge, $S \perp \chi \quad(\chi \perp(S \perp \chi), \quad[(y)] \perp(S \perp \chi), \quad[(z)])] \perp(S \perp \chi))$ and $c\left(x_{c}, y_{c}, z_{c}\right)$. Parametric equation of the cylindrical cutting tool was used to define the coordinate of both points. Point $S \chi$ is point $S$ that is rotated about the $Y$-axis by helical angle. Point $S$ is an arbitrary point on the cutting edge when $\varphi=0$, while point $c$ is a point at the bottom of the cutting edge. Let's take the coordinate of point $S$ and point $c$ for a toroidal tool as follow:

$$
s=\left(0, r_{m}, r+5\right) \text { and } c=\left(0, r_{m}, r\right)
$$

where $r_{m}$ denotes the minor radius of cutting tool. Then the coordinate of point $S \chi$ and point $c$ with respect to the engagement angle were defined by transforming them about $Y$-axis by helical angle and about $Z$-axis by engagement angle, as expressed as follows:

$$
S_{\chi}\left[\begin{array}{c}
x_{S_{\chi}} \\
y_{S_{\chi}} \\
z_{S_{\chi}}
\end{array}\right]=\operatorname{Rot}(Z, \varphi) \times \operatorname{Rot}(Y, \chi) \times[s]
$$

$$
S_{\chi}\left[\begin{array}{c}
x_{S_{\chi}} \\
y_{S_{\chi}} \\
z_{S_{\chi}}
\end{array}\right]=\left[\begin{array}{ccc}
\cos \varphi & -\sin \varphi & 0 \\
\sin \varphi & \cos \varphi & 0 \\
0 & 0 & 1
\end{array}\right] \times\left[\begin{array}{ccc}
\cos \chi & 0 & \sin \chi \\
0 & 1 & 0 \\
\sin \chi & 0 & \cos \chi
\end{array}\right] \times\left[\begin{array}{c}
x_{s} \\
y_{s} \\
z_{s}
\end{array}\right]
$$

$$
c\left[\begin{array}{l}
x_{c} \\
y_{c} \\
z_{c}
\end{array}\right]=\operatorname{Rot}(Z, \varphi) \times[c]=\left[\begin{array}{ccc}
\cos \varphi & -\sin \varphi & 0 \\
\sin \varphi & \cos \varphi & 0 \\
0 & 0 & 1
\end{array}\right]\left[\begin{array}{l}
x_{c} \\
y_{c} \\
z_{c}
\end{array}\right]
$$

The orientation of cutting tool relative to WCS due to helical angle was determined by calculating the cutting edge rotation about the $X$-axis and the $Y$-axis as depicted in Figure 2b. They were calculated as follows,

$$
\begin{gathered}
\theta_{A_{\chi}}=\tan ^{-1}\left(\frac{y_{S_{\chi}}-y_{c}}{z_{S_{\chi}}}\right) \\
\theta_{y}=\tan ^{-1}\left(\frac{x_{S_{\chi}}-x_{c}}{z_{S_{\chi}}}\right) \\
\theta_{B_{\chi}}=\tan ^{-1}\left(\frac{\left(x_{S_{\chi}}-x_{c}\right) \cos \theta_{A_{\chi}}}{z_{S_{\chi}}}\right)=\tan ^{-1}\left(\tan \theta_{y} \cos \theta_{A_{\chi}}\right)
\end{gathered}
$$

The characteristic of a free-form milling is the tool can be oriented in any direction. The tool orientation was defined using the tool orientation angles, $\theta_{A}$ and $\theta_{B}$. When a helical angle exists, the orientation angles of the cutting edge are changed. Once again, the actual cutting edge rotation can be determined with the aid of point $S \chi$ and point $c$. They are not only rotated by $\chi$, but also rotated by $\theta_{A}$ and $\theta_{B}$. Then, (13) and (15) changed to become, 


$$
\begin{aligned}
& s_{\chi}\left(x_{S_{\chi}}, y_{S_{\chi}}, z_{S_{\chi}}\right)=\operatorname{Rot}\left(X, \theta_{A}\right) \times \operatorname{Rot}\left(Y, \theta_{B}\right) \times \\
& \times \operatorname{Rot}(Z, \varphi) \times \operatorname{Rot}(Y, \chi) \cdot[s] \\
& c\left(x_{c}, y_{c}, z_{c}\right)=\operatorname{Rot}\left(X, \theta_{A}\right) \times \operatorname{Rot}\left(Y, \theta_{B}\right) \times \operatorname{Rot}(Z, \varphi) \cdot[c]
\end{aligned}
$$

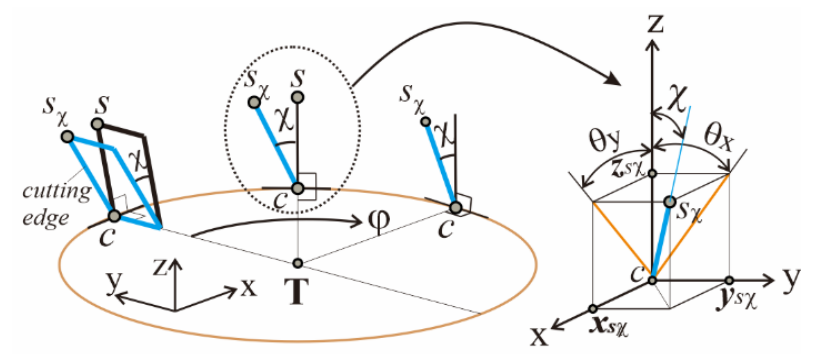

(a)

(b)

Figure 2Effect of helical angle to the cutting edge orientation with respect to the engagement angle

Once $S \chi$ and $c$ were determined, then the actual cutting edge orientations $(\theta \perp(A \perp \chi), \theta \perp(B \perp \chi))$ (could be defined using (16)- (18). Finally the mapping operator when a helical angle exist with respect to $\theta_{A \chi}$ and $\theta_{B \chi}$ was expressed by,

$$
\begin{aligned}
& {[M]_{\perp} h=\operatorname{Rot}\left(X, \theta_{\perp}\left(A_{\perp} \chi\right)\right) \times \operatorname{Rot}\left(Y, \theta_{\perp}\left(B_{\perp} \chi\right)\right)=} \\
& =\left[\begin{array}{l}
\left(\cos \theta_{\perp}\left(B_{\perp} \chi\right)\right) \& 0 \& \sin \theta_{\perp}\left(B_{\perp} \chi\right) @ \\
@ \sin \theta_{\perp}\left(A_{\perp} \chi\right) \sin \theta_{\perp}\left(B_{\perp} \chi\right) \& \cos \theta_{\perp}\left(B_{\perp} \chi\right) \& \\
\& \cos \theta_{\perp}\left(A_{\perp} \chi\right) \&-\sin \theta_{\perp}\left(A_{\perp} \chi\right) \cos \theta_{\perp}\left(B_{\perp} \chi\right) @ \\
@-\cos \theta_{\perp}\left(A_{\perp} \chi\right) \sin \theta_{\perp}\left(B_{\perp} \chi\right) \& \sin \theta_{\perp}\left(A_{\perp} \chi\right)
\end{array}\right]
\end{aligned}
$$

\subsection{Effect of helical angle to the shape of swept surface}

The shape of swept surface of a solid cutting tool is always similar whether it is with or without a helical angle. A different condition was found when a non-solid cutting tool (index-able milling tool) was used. The helical angle gave an effect to the swept surface. As depicted in Figure 3a, when a helical angle exists, the tool radius at the bottom side was different to the one at the upper side $\left(R_{\gamma}\right)$. The radius of the cutting tool equal to $R$ is only located at the bottom side.

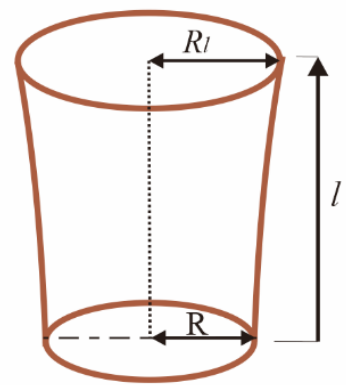

(a)

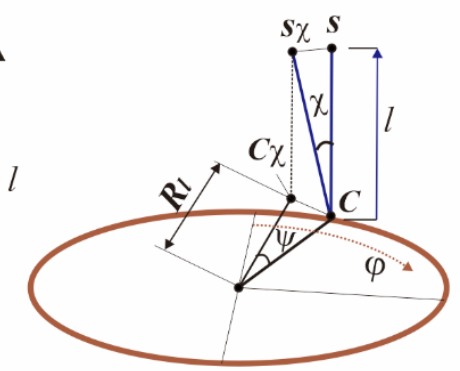

(b)
Figure 3 a) Swept surface of flat-end tool with helical angle, b) orientation of cutting edge

The tool radius increased with the increasing of the tool height $(l)$. Therefore, the actual radius of toroidal cutter as a function of axial depth of cut, $R_{\chi}(l)$, was expressed as follows,

$$
\begin{gathered}
\psi=\tan ^{-1}\left(\frac{(r-r \cos \lambda) \sin \chi}{r_{m}+r \sin \lambda}\right) \\
R_{\chi}(\lambda)=\frac{r_{m}+r \sin \lambda}{\cos \psi} \\
G_{T_{\chi}}(\varphi ; \lambda)=\left[\begin{array}{lll}
R_{\chi} \sin \varphi & R_{\chi} \cos \varphi(r-r \cos \lambda) \cos \chi
\end{array}\right]^{T}
\end{gathered}
$$

where $0<\lambda<90$ and $\psi$ is the lag angle as can be seen in Figure $3 \mathrm{~b}$. The lag angle is the engagement angle of $S \chi$ relative to the engagement angle of $S$.

\section{PATH INTERSECTION POINT}

The equation to obtain the intersection point between the swept curve of current cutting path and that of adjacent cutting path, which is called path intersection point (PI-point), was derived by referring to Figure 4. PI-point was denoted by $\mathrm{I}_{\mathrm{C}}$. Since the tool orientation was set without tilt angle, then, the angle of cc-point $(\tau)$ of the current cutting path and that of the subsequent cutting path were similar. It also made the intersection point located in between of point $c c_{1}$ and $c c_{2}$. The distance between $I_{C}$ andcc-point was calculated by,

$$
m=\frac{\left|c c_{1}-c c_{2}\right|}{2}
$$

Meanwhile the angle of the CC-point relative to the part surface was expressed as follow,

$$
t=\sin ^{-1}\left(\frac{s}{R_{1}}\right)
$$

where $R_{1}=\sqrt{R_{x}^{2}+R_{y}^{2}} . R_{x}$ and $R_{y}$ were the radius of surface curvature. The method to define the radius of surface curvatures were discussed by [8]Then, the coordinate of intersection point was mapped to tool coordinate system by $\tau$ as follows,

$$
I_{C}\left[\begin{array}{c}
x_{I_{C}} \\
y_{I_{C}} \\
z_{I_{C}}
\end{array}\right]=\left[\begin{array}{ccc}
1 & 0 & 0 \\
0 & \cos \tau & -\sin \tau \\
0 & -\sin \tau & \cos \tau
\end{array}\right] \times G_{T_{\chi}}\left(\varphi_{I_{C}} ; \lambda_{I_{C}}\right)
$$

The coordinate of $I_{C}\left(x_{I C}, y_{I C}, z_{I C}\right)$ could be defined after the toroidal angle of intersection point $\left(\lambda_{I C}\right)$ was obtained. With respect to local coordinate system, then $y_{I C}=\mathrm{m}$. Since $y_{I C}$ was identified, $\lambda_{I C}$ was then defined by extracting(27) only for $y_{I C}$ as follow,

$$
y_{I_{C}}=\left(\left(r_{m}+r \sin \lambda_{I_{C}}\right) \cos \varphi_{I_{C}}\right) \cos \tau-\left(r-r \cos \lambda_{I_{C}}\right) \sin \tau
$$

There were two unknown variables exist in $(28), \lambda_{I C}$ and $\varphi_{I C}$. Therefore, one of them need to be converted so that only one unknown variable remaining. By rearranging (10), then it was expressed by,

$$
\cos \left[\left(\varphi_{I_{C}}\right)\right]=\left[\frac{\sqrt{\left(\left(V_{T} \cdot u\right) \sin \lambda_{I_{C}}\right)^{2}-\left(\left(V_{T} \cdot w\right) \cos \lambda_{I_{C}}\right)^{2}}}{\left(V_{T} \cdot u\right) \sin \lambda_{I_{C}}}\right]
$$




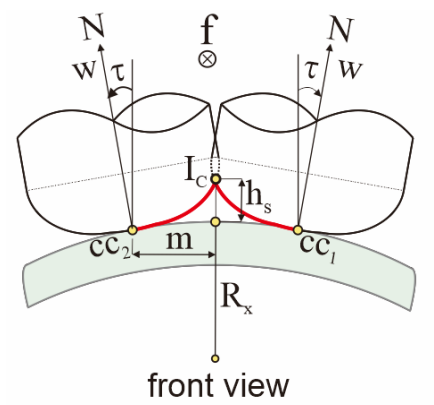

(a)

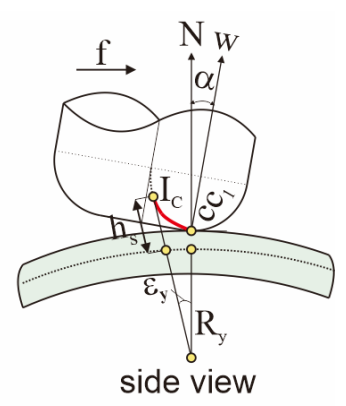

(b)
Figure 4 Intersection point of adjacent tool path, a) front view, b) side view

After converting $\cos \left[\left(\varphi_{I C}\right)\right]$ in $(28)$ by $\cos \left[\left(\varphi_{I C}\right)\right]$ in (29), finally, (28) yielded to become a polynomial equation as follow,

$$
\begin{aligned}
& \left(a^{2}\right) t^{8}+(2 a b) t^{7}+\left(2 a c+b^{2}+f^{2}\right) t^{6}+ \\
& +(2 a d+2 b c) t^{5}+\left(2 a e+2 b d+c^{2}-f^{2}\right) t^{4}+ \\
& +(2 b e+2 c d) t^{3}+\left(2 c e+d^{2}\right) t^{2}+(2 d e) t+\left(e^{2}\right)
\end{aligned}
$$

where,

$$
\begin{aligned}
& t=\sin \lambda \\
& a=\left[\left(r^{2}\left(V_{T} \cdot u\right)^{2}+r^{2}\left(V_{T} \cdot w\right)^{2}\right) \cos \varepsilon+r^{2}\left(V_{T} \cdot u\right)^{2} \sin ^{2} \tau\right] \\
& b=\left[2 r m r \cos ^{2} \varepsilon\left(\left(V_{T} \cdot u\right)^{2}+\left(V_{T} \cdot w\right)^{2}\right)\right] \\
& c=\left[\left(r_{m}^{2}\left(V_{T} \cdot u\right)^{2}+r_{m}^{2}\left(V_{T} \cdot w\right)^{2}-r^{2}\left(V_{T} \cdot w\right)^{2}\right) \cos ^{2} t\right] \\
& \left.d=\left[-2 r_{m} r\left(V_{T} \cdot u\right) \sin \tau+y\left(V_{T} \cos ^{2} \tau\right)\right)^{2}-\left(r^{2}\left(V_{T} \cdot u\right)^{2} \sin ^{2} \tau\right)\right] \\
& e=\left[-r_{m}^{2}\left(V_{T} \cdot w\right)^{2} \cos ^{2} \tau\right] \\
& f=\left[-2\left(r\left(V_{T} \cdot u\right) \sin \tau+y\left(V_{T} \cdot u\right)\right) \times r\left(V_{T} \cdot u\right) \sin \tau\right]
\end{aligned}
$$

The roots of polynomial could be determined by using software programming such as Matlab. From (30), it generated eight possibility of $t$. Among those roots, however, only one $t$ that can be converted into $\lambda_{I C}$ for obtaining intersection point correctly. The correct one was selected by following these rules,

a. $t$ must be within 0 and 1 ,

b. if more than one $t$ fulfil the first criteria, then the one that gives $y_{I C}=m$ will be selected.

Once $\lambda_{\mathrm{IC}}$ was obtained, then the engagement angle $(\varphi \perp(I \perp C))$ could be determined using (29). The coordinate of PI-point, $\mathrm{I}_{\mathrm{C}}\left(\mathrm{x}_{\mathrm{IC}}, \mathrm{y}_{\mathrm{IC}}, \mathrm{z}_{\mathrm{IC}}\right)$, was calculated using the equation below,

$$
I_{C}\left(x_{I_{C}}, y_{I_{C}}, z_{I_{C}}\right)=[M] G_{T_{\chi}}\left(\varphi_{I_{C}} ; \lambda_{I_{C}}\right)
$$

\section{SCALLOP HEIGHT CALCULATION}

The scallop height is the distance between PI-point $\left(I_{C}\right)$ and the normal point on the part surface $\left(I_{w}\right)$. In other words, it is the closest distance from the intersection point to the designed surface. Since the PI-point was obtained in previous section, in this section, the normal point will be determined. The method to define the shape of instantaneous surface refers to a hybrid analytical-discrete based methodology as proposed by [8]. Using this method, the shape of an instantaneous workpiece surface region was defined using three selected normal vectors. One of the normal vectors, which was located closest to the intersection point, $v_{1}\left(x_{v 1} ; y_{v 1} ; z_{v 1}\right)$, was used as a reference vector. A small portion of the part surface was approximated by a surface that was a combination of the surface shape in the $x$-axis $\left(S_{v x}\right)$ and $y$-axis $\left(S_{v y}\right)$ as shown in Figure 5 . The normal point will be obtained by first defining the projected point on the part surface. The projected point, $I_{\mathrm{p}}\left(x_{1 p} ; \mathrm{y}_{1 p} ; z_{1 p}\right)$, is a point which was projected vertically from the intersection point. Because it was vertical projection, then $\left(x_{1 p} ; \mathrm{y}_{1}\right)=\left(x_{\mathrm{IC}} ; \mathrm{y}_{\mathrm{IC}}\right)$. The $z_{1 p}$ was calculated by referring to Figure 5 .

$$
\begin{aligned}
& \delta_{x}=\sin ^{-1}\left(\frac{R_{x} \sin \mu_{x 1}+\left(x_{v_{1}}-x_{I_{C}}\right)}{R_{x}}\right) \\
& \delta_{y}=\sin ^{-1}\left(\frac{R_{y} \sin \mu_{y 1}+\left(y_{v_{1}}-y_{I_{C}}\right)}{R_{y}}\right) \\
& \Delta Z_{v x}=R_{x}\left(\cos \delta_{x}-\cos \mu_{x 1}\right) \\
& \Delta Z_{v y}=R_{y}\left(\cos \delta_{y}-\cos \mu_{y 1}\right)
\end{aligned}
$$

Once the displacement of projected point from the reference normal vector $\left(v_{1}\right)$ in z-axisof $S_{v x}\left(\Delta \mathrm{Z}_{\mathrm{vx}}\right)$, as shown in Figure 5a, and that of $S_{v y}\left(\Delta \mathrm{Z}_{\mathrm{vy}}\right)$, as shown Figure $5 \mathrm{~b}$, are determined, then the coordinate of the projected point was defined as follow,
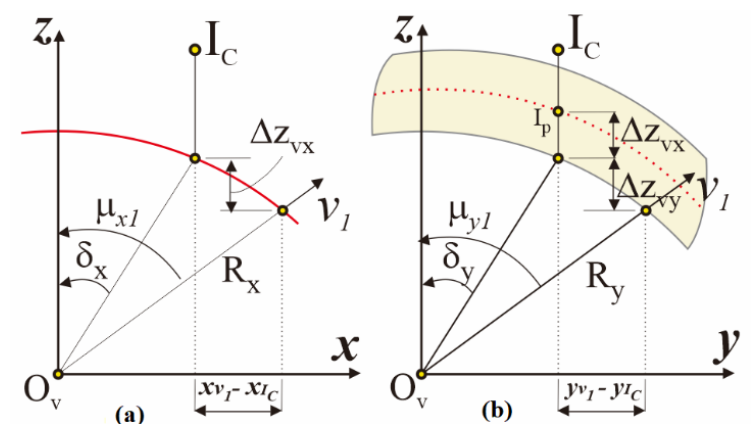

Figure 5 a) Rotation of the projection line on $S_{v x}$, b) rotation of the projection line on $S_{v y}$

$$
I_{p}\left(x_{I_{p}} ; y_{I_{p}} ; z_{I_{p}}\right)=\left(x_{I_{C}} ; y_{I_{C}} ;\left(Z_{v 1}+\Delta Z_{w x}+\Delta Z_{w y}\right)\right)
$$

By working on surface $S_{p y}$, which was the surface where the point $I_{p}$ was located, then point $I_{g}$ could be defined. $I_{g}$ is an intersection point between the line $O p I c$ and surface $S_{p y}$ as depicted in Figure 6a. Before point $I_{g}$ was defined, the orientation of point $I_{g}$ relative to the surface in $Y$-axis $\left(\varepsilon_{y}\right)$ should be determined. Therefore, $I_{g}$ and $\varepsilon_{y}$ were calculated by,

$$
\varepsilon_{y}=\tan ^{-1}\left(\frac{R_{y} \sin \delta_{y}}{\left(z_{I_{C}}-z_{I_{p}}\right)+\left(R_{y} \cos \delta_{y}\right)}\right)
$$




$$
I_{g}\left(x_{I_{g}} ; y_{I_{g}} ; z_{I_{g}}\right)=\left[\begin{array}{c}
x_{I_{p}} \\
y_{I_{p}}-R_{y}\left(\sin \delta_{y}-\sin \varepsilon_{y}\right) \\
z_{I_{p}}+R_{y}\left(\cos \varepsilon_{y}-\cos \delta_{y}\right)
\end{array}\right]
$$

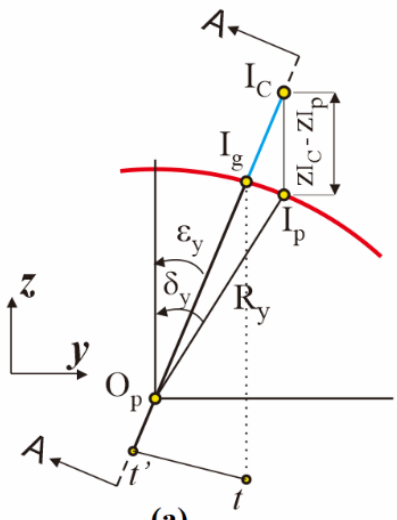

(a)

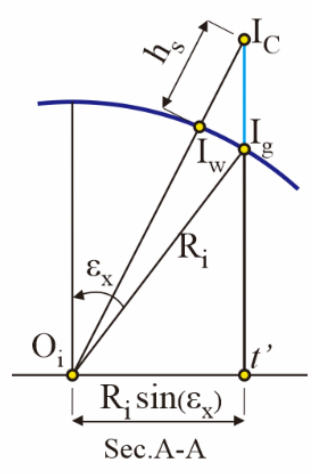

(b)
Figure 6 a) Section A-A of surface $S_{p y}$, b) inclined surface

The scallop height was then determined by working on the surface of section A-A. This surface was surface $S_{p x}$ which was inclined by $\varepsilon_{y}$. The inclined surface is presented inFigure $6 \mathrm{~b}$. The radius of inclined surface, the orientation of $I_{g}$ relative to the inclined surface $\left(\varepsilon_{y}\right)$, and the distance of point $I_{C}$ to point $t$ ' were determined as follow,

$$
\begin{aligned}
& R_{i}=\frac{R_{x}}{\cos \varepsilon_{y}} \\
& \varepsilon_{x}=\sin ^{-1}\left(R_{x} \sin \frac{\delta_{x}}{R_{i}}\right) \\
& \overline{I_{C} t^{\prime}}=\left|I_{C}-I_{g}\right|+R_{i} \cos \varepsilon_{x}
\end{aligned}
$$

Finally, the scallop height was defined using the triangle of $O_{i}-I_{C}-t^{\prime}$, as shown in Figure $6 \mathrm{~b}$ and it was expressed by,

$$
h_{s}=\sqrt{\left(\overline{I_{C} t^{\prime}}\right)^{2}+\left(R_{i} \sin \varepsilon_{x}\right)^{2}}-R_{i}
$$

\section{IMPLEMENTATION AND DISCUSSION}

Based on the formulae derived in the previous section, a simulation program using Matlab has been developed. The proposed method in this study was called Grazing Toroidal Approximation (GTA). In this section, the proposed method was tested for a model test as can be seen inFigure 7a. The verification wasperformed using large step-over. It was aimed to get high scallop so that the verification can be performed easier. In this test, 15 $\mathrm{mm}$ step-over was selected. The machining conditions used in the test were feedrate $0.3 \mathrm{~mm} /$ tooth and spindle speed $5000 \mathrm{rpm}$. A two teeth toroidal cutter with helical angle 10 , diameter $20 \mathrm{~mm}$ and a minor radius of $5 \mathrm{~mm}$ was used as the cutting tool. Using GTA, the shape of machined surface can be generated as can be seen inFigure 7b. Moreover, the coordinate of the inter-section point can be determined, and hence the scallop height can be calculated. The detailed shape of the scallop and the intersection point were shown in Figure 7c. The proposed method was verified using the commercial software Siemens-NX. The shape of part surface after machining using Siemens-NX is presented in Figure 7a. From Figure $7 \mathrm{a}$ and Figure $7 \mathrm{~b}$ can be seen that the shape of scallop generated using Siemens-NX resembled the shape of scallop generated using the program simulation. Although the shape of machined surfaces was similar, the accuracy of the proposed method had to be examined. Verification was performed by comparing the scallop height calculated using the proposed method with those measured using Siemens-NX. The method to measure cutter workpiece engagement in Siemens-NX was explained in $[6,8]$. The scallop height of every cc-points for one tool pass were compared, and the results are shown in Figure 7d. From this graph, it is shown that all of the tests produced relatively small errors.

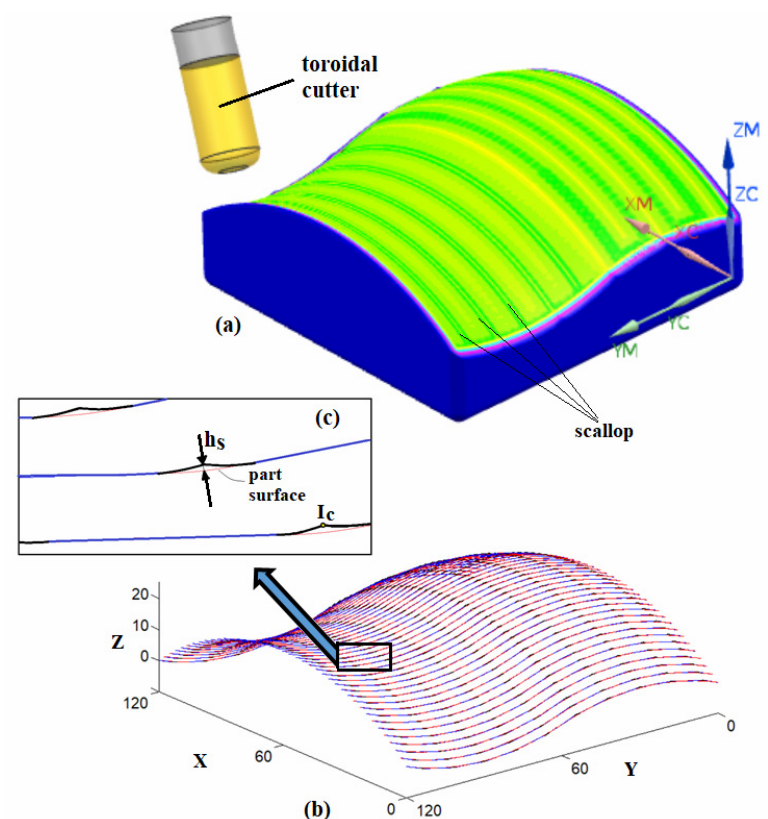

(b) $\quad 0 \quad 120$

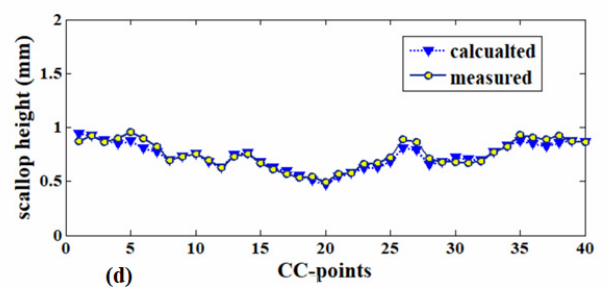

Figure 7 a) machined surface generated using Siemens-NX, b) machined surface generated using proposed method, c) the shape of scallop, d) calculated and measured scallop height

The ability of the proposed method to check the effect of helical angle to the scallop was also performed. For verification, the part as shown in Figure 8a was examined. The machining conditions used in the test were feedrate $0.3 \mathrm{~mm} /$ tooth, step-over $10.49 \mathrm{~mm}$ and spindle speed $5000 \mathrm{rpm}$. A two teeth toroidal cutter with diameter $20 \mathrm{~mm}$ and a minor radius of $5 \mathrm{~mm}$ was used as the cutting tool. The inclination angle was set to decrease gradually during the ramp-up machining process. In this test, the scallop height produced by the toroidal tool with five different helical angles, $0,10,20$, 30, 40, were compared. 

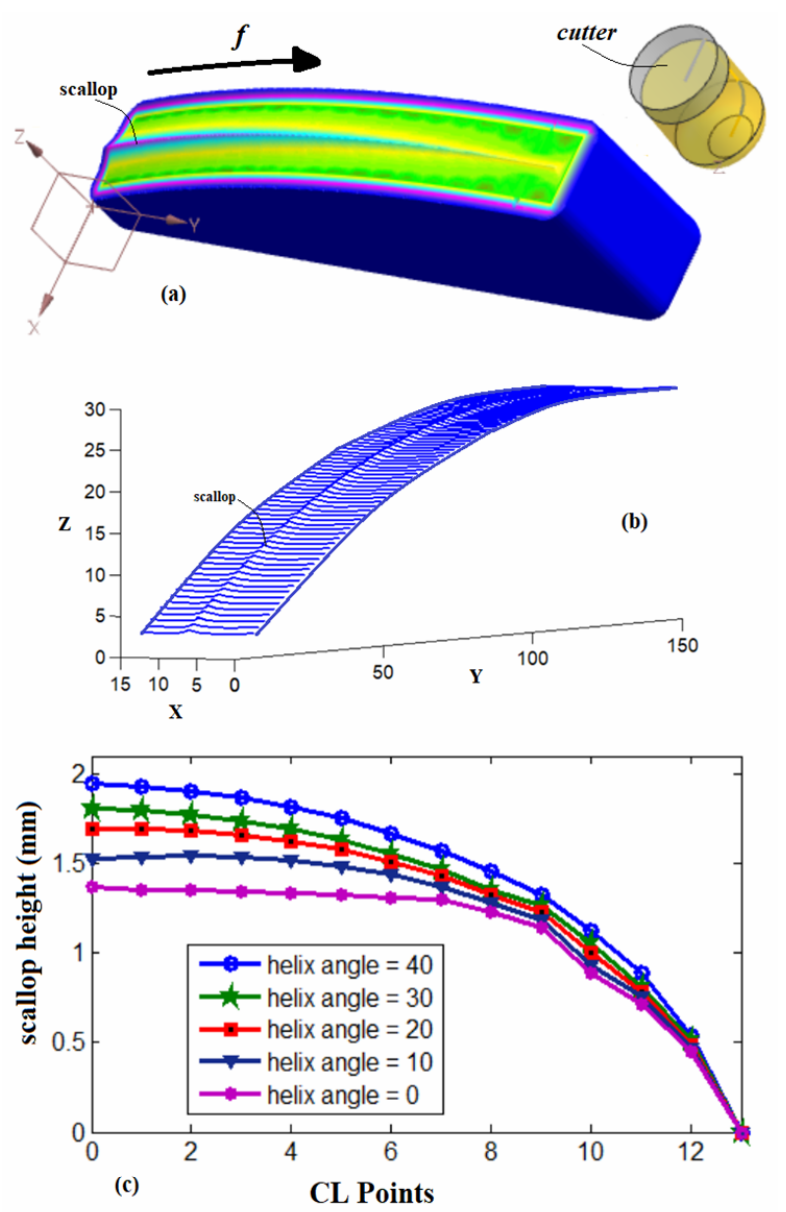

Figure 8 a) model test, b) shape of scallop, c) scallop height for various helical angles

Using GTA, the shape of machined surface for one tool pass was generated, as shown in Figure $8 \mathrm{~b}$. The scallop height of every CC-points for all tests were calculated and the results were presented in Figure 8c. From this figure can be taken into conclusion that:at the same machining condition, the helical angle tend to decrease the scallop height. Moreover, decreasing the inclination angle will decrease the scallop height.

\section{CONCLUSION}

In this study, a new method, known as the Grazing Toroidal Approximation, was developed to generate the scallop height of helical toroidal cutter during free-form machining in five-axis milling. The primary contributions of this study include the following;

a. The GTA is applicable to calculate the scallop height of helical toroidal cutter in five-axis milling process. It was tested using one-part model.

b. The verification test proved that GTA is accurate. It was verified by comparing the scallop height obtained using the GTA with those measured using Siemens-NX.

c. From the test it was found that increasing helical angle will decrease the scallop height. On the other hand, decreasing the inclination angle will decrease the scallop height.

The proposed algorithm is applicable for calculating the scallop height of five-axis milling using non-solid cutter (insert cutter). In the future, the method for solid cutter will be developed. Geometrically, solid cutting tool is more complex than non-solid cutter.

\section{ACKNOWLEDGMENT}

The author appreciates the funding provided by the Indonesian Ministry of Research, Technology and Higher Education through the fundamental research grant scheme.

\section{REFERENCES}

[1] Tóth-Laufer, E. and Horváth, R.: Fuzzy model based surface roughness prediction of fine turning, FME Transactions, Vol. 45, No.1, pp. 181188, 2017.

[2] Feng, H. Y., and Li, H.: Constant scallop-height tool path generation for three-axis sculptured surface machining, Computer-Aided Design, Vol. 34, No.9, pp. 647-654, 2002.

[3] Lin, R. S.and Koren, Y.: Efficient tool-path planning for machining free-form surfaces, Journal of Engineering for Industry, Vol. 118, No. 1, pp. 20-28, 1996.

[4] Sarma, R. and Dutta, D: The geometry and generation of NC tool paths, Journal of Mechanical Design, Vol. 119, No. 2, pp. 253-258, 1997.

[5] Zhang, X. F., Xie, J., Xie, H. F. and Li, L. H.: Experimental investigation on various tool path strategies influencing surface quality and form accuracy of CNC milled complex freeform surface, International Journal of Advanced Manufacturing Technology, Vol. 59, No. 5-8, pp. 647-654, 2012.

[6] Kiswanto, G., Hendriko, H., Duc, E.:An analytical method for obtaining cutter workpiece engagement during a semi-finish in five-axis milling,ComputerAided Design, Vol.55, pp. 81-93, 2014.

[7] Hendriko, H.: Mathematical model for chip geometry calculation in five-axis milling, Jurnal Teknologi, Vol. 77, No. 23, pp. 107-112, 2015.

[8] Kiswanto, G., Hendriko, H., Duc, E.: A hybrid analytical and discrete based methodology for determining cutter workpiece engagement in five axis milling, International Journal of Advanced Manufacturing Technology, Vol. 80, No. 9,pp. 2083-2096, 2015.

[9] Ozturk, E., Tunc, L. T., Budak, E.: Investigation of lead and tilt angle effects in 5-axis ball-end milling processes, International Journal of Machine Tools and Manufacture, Vol. 49, No. 14, pp. 10531062, 2009.

[10] Gilles, P., Cohen, G., Monies, F.and Rubio, W.: Torus cutter positioning in five-axis milling using balance of the transversal cutting force, International Journal of Advanced Manufacturing Technology, Vol. 66, No. 5-8, pp. 965-973, 2013.

[11]Fan, J.and Ball, A.: Quadric method for cutter orientation in five-axis sculptured surface machining, International Journal of Machine Tools and Manufacture, Vol. 48, No. 7, pp. 788801, 2008. 
[12] Sadílek, M., Čep, R., Budak, I.andSoković, M.: Aspects of using tool axis inclination angle, Strojniški vestnik-Journal of Mechanical Engineering, Vol. 57, No. 9, pp. 681-688, 2011.

[13] Sadilek, M., Fojtík, F., Sadílková, Z., Kolařík, K.and Petrů, J.: A Study of Effects of Changing the Position of the Tool Axis against the Machined Surface, Transactions of FAMENA, Vol. 39, No. 2, pp. 33-46, 2015.

[14]Bedi, S., Ismail, F., Mahjoob, M. J.and Chen, Y.: Toroidal versus ball nose and flat bottom end mills, International Journal of Advanced Manufacturing Technology, Vol. 13, No. 5, pp. 326-332, 1997.

[15] Warkentin, A., Bedi, S.and Ismail, F.: Five-axis milling of spherical surfaces, International Journal of Machine Tools and Manufacture, Vol. 36, No. 2, pp. 229-243, 1996.

[16] Senatore, J., Segonds, S., Rubio, W. and Dessein, G.: Correlation between machining direction, cutter geometry and step-over distance in 3-axis milling: Application to milling by zones, Computer-Aided Design, Vol. 44, No. 12, pp. 1151-1160, 2012.

[17] Vickers, G. W. and Quan, K. W.: Ball-mills versus end-mills for curved surface machining, Journal of Engineering for Industry, Vol. 111, No. 1, pp. 2226, 1989.

[18] Duvedi, R. K., Batish, A., Bedi, S. and Mann, S.: Scallop height of 5-axis machining of large triangles with a flat end mill, Computer-Aided Design and Applications, Vol. 12, No. 6, pp. 710716, 2015.

[19] Feng, H. Y. and Li, H.: Constant scallop-height tool path generation for three-axis sculptured surface machining, Computer-Aided Design, Vol. 34, No. 9, pp. 647-654, 2002.

[20] Lin, R. S., Koren, Y.: Efficient tool-path planning for machining free-form surfaces, Journal of Engineering for Industry, Vol. 118, No. 1, pp. 20-28, 1996.

[21] Wang, P., Zhang, S. and Yan, Z. G.: Study on surface defects in five-axis ball-end milling of tool steel, International Journal of Advanced Manufacturing Technology, Vol 89, No. 1-4, pp. 599-609, 2017.

[22] Yigit, I. E. and Lazoglu, I.: Analysis of tool orientation for 5-axis ball-end milling of flexible parts, CIRP Annals-Manufacturing Technology, Vol. 64, No. 1, pp. 97-100, 2015.

\section{ХИБРИДНА АНАЛИТИЧКО-ДИСКРЕТНА МЕТОДОЛОГИЈА ЗА ИЗРАЧУНАВАЊЕ ПУТАЫЕ РЕЗНЕ ИВИЦЕ КОД ХЕЛИКОИДНОГ ТОРОИДНОГ РЕЗНОГ АЛАТА ПРИ ПЕТООСНОМ ГЛОДАЫУ}

\section{Х. Хендрико}

Приказан је нови метод за израчунавање путање висине гребена тороидног резног алата код обраде слободних површина петоосним глодањем. Висина гребена је дефинисана као растојање између тачке пресека алата и тачке нормалне на површину дела који се обрађује. Тачка пресека алата је одређена аналитички помоћу методе стањивања у циљу дефинисања широке криве код тороидног резног алата. У међувремену је одређена површина нормална на површину дела применом хибридне аналитичко-дискретне методологије. Површина дела је дискретизована са неколико нормалних вектора, који су потом употребљени за математичко одређивање површине дела. У овој студији је приликом развоја модела размотрен ефекат хеликоидног угла резне ивице. Предложени модел је успешно искоришћен за генерисање података за путању резне ивице за два дела са слободним површинама на моделу. Утицај хеликоидног угла на висину гребена је тестиран и резултати показују да хеликоидни угао тежи да смањи висину гребена. Тест верификације за проверу прецизности предложеног метода је примењен и резултати показују да је метод прецизан. 